\title{
Regulation of the expression and activity by progestins of a member of the $S O X$ gene family of transcriptional modulators
}

\section{J D Graham, S M N Hunt, N Tran and C L Clarke}

Westmead Institute for Cancer Research, University of Sydney, Westmead Hospital, Westmead, New South Wales 2145, Australia

(Requests for offprints should be addressed to C Clarke, Department of Medical Oncology, Westmead Hospital, Westmead, New South Wales 2145, Australia)

(J D Graham is now at Department of Medicine, University of Colorado Health Sciences Centre, 4200 E. 9th Avenue, Campus Box B151, Denver, Colorado, USA)

\begin{abstract}
The mammalian testis-determining gene Sry and the related Sox genes define a family of transcriptional regulators widely expressed during embryogenesis. Tightly controlled temporal profiles of expression are a feature of the Sox gene family and may be required for initiation of a cascade of gene expression, yet the molecular mechanisms that control Sox gene expression are unknown. We now show that human SOX4 is expressed in the normal breast and in breast cancer cells. In these cells $S O X 4$ is a progesterone-regulated gene, the expression of which is increased by progestins, leading to a marked increase in SOX-mediated transcriptional activity. Treatment of T-47D breast cancer cells with the synthetic progestin ORG 2058 directly increased SOX 4 transcription, resulting in a 4 -fold increase in SOX4 mRNA levels within $4 \mathrm{~h}$ of treatment. No effect of ORG 2058 was noted on other $S O X$ genes measured, nor were other hormone-regulated HMG box proteins detected in this system, suggesting that the observed ability of
\end{abstract}

progestin to increase SOX mRNA expression was confined to SOX4. The increase in SOX4 transcription was reflected in increased SOX4 protein expression, as progestin treatment of T-47D cells transfected with a SOX-responsive reporter resulted in a marked increase in reporter gene expression. Progesterone is essential for normal development and differentiation of the female reproductive system, plays an essential role in regulating growth and differentiation of the mammary gland and is required for opposing the proliferative effects of estrogen in specific cell types. The detection of SOX4 expression in the normal and malignant breast and the demonstration that SOX4 expression is under progesterone control suggests that changes in $S O X 4$ gene expression may play a role in commitment to the differentiated phenotype in the normal and malignant mammary gland.

Fournal of Molecular Endocrinology (1999) 22, 295-304

\section{INTRODUCTION}

The SOX4 gene is a member of a family of transcription regulators which all contain an HMG box DNA-binding domain, and interact with DNA in a sequence-specific fashion (Pevny \& Lovell-Badge 1997). Many SRY-related HMG box $(S O X)$ genes have now been identified in the human, as well as other species, on the basis of their homology in this region. Where analysed, all have been shown to bind specifically to the doublestranded DNA motif, A/TA/TCAAA/TG (Denny et al. 1992, van de Wetering \& Clevers 1992, Laudet et al. 1993, van de Wetering et al. 1993, Connor et al. 1995, Hosking et al. 1995). Interaction of HMG box proteins with this motif results in bending of the DNA, suggesting that transactivation by these factors may occur by facilitating protein-protein or protein-DNA interactions, bringing normally distal components into proximity with each other (Ferrari et al. 1992). Although it is still not possible to ascribe functions to all members of the Sox gene family, there is increasing evidence that Sox proteins are likely to be involved in many 
aspects of transcriptional regulation (Pevny \& Lovell-Badge 1997). Their role as transcriptional regulators, combined with their limited tissue distribution and diverse patterns of distribution during embryogenesis, suggest that members of the Sox gene family play a pivotal role in cell fate determination in a wide range of developmental processes (Pevny \& Lovell-Badge 1997). More recent evidence has implicated aberrant expression of Sox genes in malignancy: SOX21 expression has been associated with metastatic potential in melanoma cell lines (Tani et al. 1997), and aberrant expression of SOX4 in colon carcinoma has been implicated in regulation of the expression of $\mathrm{p} 56^{l c k}$, a member of the $s r c$ family of tyrosine kinases (McCracken et al. 1997).

The Sox4 gene, first isolated from a mouse embryo cDNA library as the Sry-related gene a4 (Gubbay et al. 1990), is specifically expressed in the ovary, testis and thymus of adult mice and in mouse $\mathrm{T}$ and pre-B lymphocytic cell lines (van de Wetering et al. 1993). Sox4 has transactivating capacity when cotransfected into Sox4-negative T cells with a reporter plasmid containing seven copies of the AACAAAG motif. It was found that binding of at least two Sox 4 transactivation domains was required to see this effect in the absence of other enhancer elements, suggesting that Sox4 may cooperate with other transcription factors to exert tissue-specific control of gene expression (van de Wetering et al. 1993). Evidence is now emerging that cooperative function between Sox proteins and other transcription factors may be a general feature: Sox2 cooperates with one of the POU domain factors, Oct-4, in the regulation of osteopontin expression in preimplantation development (Botquin et al. 1998). Sox2 is also involved in transcriptional regulation of the $F G F-4$ gene, in cooperation with Oct-3 and Sp1/Sp3 (Lamb \& Rizzino 1998). Sox11 and Sox4 cooperate with another POU protein, Brn-1, in glial cells (Kuhlbrodt et al. 1998). Sox4 cooperates also with the transcription factor Ets-1 in regulating the expression of $\mathrm{p} 56^{l c k}$ (McCracken et al. 1997).

During embryogenesis Sox4 is essential for normal cardiac development. Transgenic mice harbouring a homozygous mutation in Sox4 die during embryogenesis because of a failure in endocardial ridge development which prevents proper formation of semilunar valves, resulting in circulatory failure (Schilham et al. 1996). Furthermore, introduction of bone marrow cells from these animals into an irradiated host results in a block in $\mathrm{B}$-cell lineage progression at the stage of pro-Blymphocyte expansion (Schilham et al. 1996). This indicates that Sox4 is involved in developmental processes occurring both in embryogenesis and in the mature animal.

Although murine Sox 4 is expressed in the ovary and testis, which are steroid hormone-responsive tissues, there is no information on steroidal regulation of $S O X 4$ gene expression. SOX4 was identified in searching for genes that were early targets of progestin action: human $S O X 4$ was detected in the progesterone receptor (PR)-positive T-47D breast cancer cell line as a progestinregulated gene. Progestin regulation of $S O X 4$ may represent an intermediate step in downstream progestin effects in the normal and malignant breast.

\section{MATERIALS AND METHODS}

\section{Materials}

The general chemicals used were of molecular biological or analytical reagent grade, as required by specific methodology, and were from the same sources as previously listed (Clarke et al. 1990). Radiochemicals, ORG 2058, Moloney murine leukaemia virus reverse transcriptase, Taq DNA polymerase and Megaprime DNA labelling system were obtained from Amersham Australia (North Ryde, Sydney, Australia). The pSG5-hPR1 plasmid was a gift from Dr P Chambon (Strasbourg, France) and has been described previously (Kastner et al. 1990). Oestradiol-17 $\beta$ was a Sigma (St Louis, MO, USA) product. ICI 182780 was a gift from Dr Alan Wakeling, Zeneca (Macclesfield, UK) and RU 38486 was a gift from Dr J P Raynaud, Roussel-Uclaf (Romainville, France). The pBL2CAT-[SOX4] $]_{4}$ plasmid containing four SOX4-binding motifs (AACAAAG) upstream of the thymidine kinase promoter and chloramphenicol acetyltransferase (CAT) sequences was a gift from Dr G E O Muscat, University of Queensland (Brisbane, Australia). The following oligonucleotide sequences were identified from the GenBank DNA sequence database and were obtained from Bresatec (Adelaide, SA, Australia) or from Pacific Oligos (Lismore, NSW, Australia) and used as probes or PCR primers as described in the text: SOX4F1, 5'-AGGAGTTGAGGGGCCAGTTC-3'; SOX4R1， 3'-CACTGCCACCGACCTTGTCTC-5'; SOX2R, 3'-CACATGTGTGAGAGGGGCAGT GTG-5' (nucleotides 942-965); SOX3R, 3'-CAGT CTCCAGAAGGCTGTACATTG-5' (nucleotides 665-688); SOX11R, 3'-GTTGCTCTCCGCTTC CAAGCTCTC-5' (nucleotides 91-114); mSox21F1, 5'-CTCAGGCTTGGCAGTGGA-3' (nucleotides 2363-2380); mSox21R1, 3'-AGGCTGGGTGGA TTGCCT-5' (nucleotides 2982-2999); SOX22F1, 
5'-TGTAGAGCGATCCTGGGA-3' (nucleotides 1894-1911); SOX22R1, 3'-CAGTCTCACTGGC CAAGT-5' (nucleotides 2486-2503). The plasmid pSox9.5a (Wright et al. 1995) containing a $500 \mathrm{bp}$ fragment of Sox9 cDNA was a gift from Dr P Koopman, University of Queensland. A partial rat glyceraldehyde phosphate dehydrogenase (GAPDH) cDNA was a gift from $\mathrm{Mr} \mathrm{G}$ Brown (CSIRO, North Ryde, Australia) and was used as a probe for human GAPDH.

\section{Cell culture}

T-47D human breast cancer cells (Keydar et al. 1979) were obtained from E G and G Mason Research Institute, Worcester, MA, USA and stocks were maintained in virtually continuous exponential growth in phenol red-free RPMI 1640 medium containing $10 \%$ fetal calf serum (FCS) as described previously (Clarke et al. 1990).

\section{Differential display reverse transcription (RT) PCR and cDNA cloning}

T-47D cells, growing exponentially in phenol red-free RPMI 1640 medium containing 10\% FCS, were treated in duplicate for $6 \mathrm{~h}$ with $10 \mathrm{nM}$ ORG 2058 or vehicle. The cells were harvested and total RNA was prepared separately from duplicate control and progestin-treated pairs. The differential display method used was derived from the protocols of Liang and colleagues (Liang et al. 1992, 1993). Total RNA $(5 \mu \mathrm{g})$ was annealed to a degenerate primer mix $(2.5 \mu \mathrm{M}$ each oligonucleotide) with general sequence $\mathrm{T}_{11} \mathrm{YC}$ (where $\mathrm{Y}=\mathrm{A}, \mathrm{C}$ or $\mathrm{G}$ ). RT was performed using Moloney murine leukaemia virus reverse transcriptase with $50 \mathrm{mM}$ Tris, $\mathrm{pH}$ 8.2, $50 \mathrm{mM} \mathrm{KCl}, 6 \mathrm{mM} \mathrm{MgCl}_{2}, 20 \mu \mathrm{M}$ dNTP mix and $20 \mathrm{U}$ RNasin RNase inhibitor (Promega Corp., Annandale, Australia), by incubation at $35^{\circ} \mathrm{C}$ for $1 \cdot 5 \mathrm{~h}$. PCR mixtures containing $3 \mu \mathrm{l}$ RT product, $2 \cdot 5 \mu \mathrm{M} 3$ '-primer mix (as for reverse transcription), $0 \cdot 5 \mu \mathrm{M}$ each $5^{\prime}$-CTGACCAGCC and $5^{\prime}$-GGGAG ACATC oligonucleotide primers, $2 \mu \mathrm{M}$ dNTP mix, $12 \mu \mathrm{Ci}\left[{ }^{35} \mathrm{~S}\right] \mathrm{dATP}(1500 \mathrm{Ci} / \mathrm{mmol}), 1.5 \mathrm{mM} \mathrm{MgCl}{ }_{2}$, $1 \mathrm{U}$ Taq DNA polymerase and reaction buffer (supplied), were denatured at $90{ }^{\circ} \mathrm{C}$ for $1 \mathrm{~min}$, followed by 40 PCR cycles. PCR conditions were: denaturation for $30 \mathrm{~s}$ at $90{ }^{\circ} \mathrm{C}$, annealing at $40{ }^{\circ} \mathrm{C}$ for $1 \mathrm{~min}$, and extension at $72^{\circ} \mathrm{C}$ for $30 \mathrm{~s}$, followed by a final incubation at $72{ }^{\circ} \mathrm{C}, 5 \mathrm{~min}$. Amplified products were analysed by electrophoresis through denaturing $8 \%$ acrylamide gels at $50{ }^{\circ} \mathrm{C}$. Gels were dried on to Whatman 3MM paper and exposed to film overnight.
A differentially displayed band of $99 \mathrm{bp}$ was excised and reamplified using the same PCR conditions as above except that the dNTP concentration in the reaction was increased 10 -fold to $20 \mu \mathrm{M}$. The reamplified PCR products were inserted into the pGEM-T vector (Promega Corp.) and sequenced using an ABI 373A automated DNA sequencing system (Applied Biosystems, Warrington, Cheshire, UK). Sequences were compared with the GenBank and EMBL databases using the National Center for Biotechnology Information BLAST local alignment network service (Altschul et al. 1990).

cDNA clones were obtained by screening a human breast carcinoma $\lambda \mathrm{gt} 11$ cDNA library derived from the ZR-75-1 cell line (Clontech, Palo Alto, CA, USA). Positive phage clones were propagated and purified essentially as described by Sambrook et al. (1989). cDNA inserts were excised using EcoRI and subcloned into the EcoRI site of pGEM-7Zf(+). The identity of positive clones to SOX4 was confirmed by DNA sequencing and alignment to the GenBank and EMBL database using the BLAST network service (Altschul et al. 1990). An 800 bp SOX 4 fragment corresponding to sequences $[+1612,+2412]$ of the gene was isolated using this approach.

\section{PCR amplification of SOX sequences}

Partial cDNA fragments were amplified by PCR from human genomic DNA using SOX4- or SOX22-specific primers and from mouse genomic DNA using Sox21-specific primers. PCR reactions containing $50 \mathrm{ng}$ DNA, $0 \cdot 3 \mu \mathrm{M}$ each oligonucleotide primer SOX4F1 and SOX4R1, $2 \mu \mathrm{M}$ dNTPs, $1.5 \mathrm{mM} \mathrm{MgCl}_{2}, 1.25 \mathrm{U}$ Taq DNA polymerase and $1 \times$ reaction buffer (supplied), were denatured at $95{ }^{\circ} \mathrm{C}$ for $5 \mathrm{~min}$ followed by $30 \mathrm{PCR}$ cycles $\left(95^{\circ} \mathrm{C}\right.$, $30 \mathrm{~s} ; 60^{\circ} \mathrm{C}, 30 \mathrm{~s} ; 72{ }^{\circ} \mathrm{C}, 30 \mathrm{~s}$ ) and a final extension step at $72{ }^{\circ} \mathrm{C}$ for $10 \mathrm{~min}$. The PCR product, SOX22F1R1, was used as the HMG-box specific probe. Similar reactions were set up for Sox21 and SOX22 using msox $21 \mathrm{f} 1$ and $\operatorname{msox} 21 \mathrm{r} 1$ or SOX22F1 and SOX22R1 except that an annealing temperature of $52{ }^{\circ} \mathrm{C}$ was used. Amplification of a single band of expected size was confirmed by analysis of an aliquot of the PCR reaction on a $1 \cdot 2 \%$ agarose gel. The PCR products were purified from the remaining reactions using the JETquick kit (Genomed Inc, Research Triangle Park, NC, USA) and labelled using the Amersham Megaprime DNA labelling system using $\left[\alpha-{ }^{32} \mathrm{P}\right] \mathrm{ATP}$ for use as HMG-box, SOX21- and SOX22-specific probes respectively. Oligonucleotides SOX2R, SOX3R and SOX11R were 
end-labelled using $\left[\gamma_{-}{ }^{32} \mathrm{P}\right] \mathrm{ATP}$ and T4 polynucleotide kinase and used as probes for SOX2, SOX3 and SOX11 respectively.

\section{RNA isolation and Northern blot analysis}

T-47D cells growing exponentially in phenol red-free RPMI 1640 medium containing 5\% FCS were changed 3 or 4 days after plating into phenol red-free RPMI 1640+1\% charcoal-stripped FCS and incubated for a further $24 \mathrm{~h}$, then treated as described in the figure legends and text. After harvesting the cells, total RNA was isolated by the guanidinium isothiocyanate/cesium chloride method and poly(A) ${ }^{+}$RNA extracted using the PolyATtract mRNA isolation kit (Promega, Madison, WI, USA). Northern blot analysis was performed as described previously (Clarke et al. 1990). The SOX4 and hPR1 cDNA probes were labelled using the Amersham Megaprime DNA labelling system. Total RNA was also isolated from normal breast tissue derived from reduction mammoplasty and analysed in the same way. The 18S oligonucleotide probe was end-labelled using $\left[\gamma-{ }^{32} \mathrm{P}\right] \mathrm{ATP}$ and T4 polynucleotide kinase. Results were analysed using a Molecular Dynamics (Sunnyvale, CA, USA) PhosphorImager and Imagequant software.

\section{Nuclear run-on}

SOX4 and PR gene transcription rates were estimated using the method of Greenberg \& Ziff (1984) with modifications, as described previously (Clarke et al. 1991). Labelled run-on transcripts were hybridized to nitrocellulose filters, on which $5 \mu \mathrm{g}$ each of linearized SOX $4[+1612,+2412]-$ pGEM7, pSG5-hPR1, pGEM-7Zf $(+)$ and ba1 ( $\alpha$-tubulin) (Cowan et al. 1983) plasmids had been slot blotted and fixed by UV irradiation. Filters were washed (Clarke et al. 1991), dried and exposed to a phosphor screen and later to film. The results were scanned and analysed using a Molecular Dynamics PhosphorImager and Imagequant software. To control for differences in hybridization, SOX4 and PR signals were normalized using the $\alpha$-tubulin signal on the same filter.

\section{Gene transfection}

T-47D cells were plated into $25 \mathrm{~cm}^{2}$ flasks $\left(5 \times 10^{5}\right.$ cells/flask) in RPMI 1640 phenol red-free medium containing 5\% FCS 2 days before transfection, and changed to Dulbecco's modified Eagle's medium supplemented with 5\% FCS on the day of transfection. Cells were transfected by the calcium

\section{Human SOX4

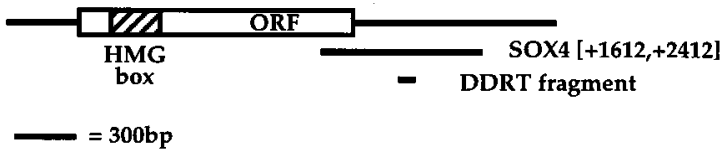

FIGURE 1. Identification of SOX4 fragments by differential display. The figure shows the schematic map of the SOX 4 cDNA indicating the locations of the $99 \mathrm{bp}$ fragment identified by differential display RT-PCR and the 800 bp SOX4 fragment isolated from the cDNA library. The coding region of SOX4 is boxed and the HMG box is indicated as the hatched region.

phosphate precipitation method (Gorman 1985) as described previously (Clarke et al. 1991), with pBL2CAT-[SOX 4$]_{4}(5 \mu \mathrm{g} /$ flask $)$ and $1 \mu \mathrm{g}$ pCH110 $\beta$-galactosidase control plasmid. The cells were subjected to osmotic shock $4 \mathrm{~h}$ after addition of precipitates, after which the precipitates were returned to the flasks and drug treatments were added. Cells were given fresh medium (containing the appropriate drug concentrations) $16 \mathrm{~h}$ after osmotic shock, and harvested $8 \mathrm{~h}$ later. Enzyme activities and protein concentrations were measured in cell lysates as described previously (Clarke et al. 1991).

\section{RESULTS}

\section{Detection of $S O X 4$ as a progestin- regulated gene}

Progestin induction of the SOX4 gene was demonstrated by differential display RT-PCR in the PR-positive T-47D breast cancer cell line. Sequence analysis of the RT-PCR product showed it was identical to a $3^{\prime}$ region of the human $S O X 4$ gene (Fig. 1). This region is unique to SOX4 and has low identity with other $S O X$ gene family members. The SOX4 transcript was detected on Northern blots as a single band migrating ahead of the $28 \mathrm{~S}$ ribosomal subunit in total RNA (Fig. 2A), consistent with the previous characterization of the SOX 4 mRNA as a major transcript of $5 \cdot 2 \mathrm{~kb}$ (Farr et al. 1993).

\section{Characterization of SOX4 mRNA regulation}

SOX4 mRNA levels were induced by treatment of T-47D cells with the synthetic progestin ORG 2058 (Fig. 2A). The increase was detectable within $1 \mathrm{~h}$ of treatment and reached a maximum, approximately 4 -fold the time-matched control, by $4 \mathrm{~h}$ after treatment (Fig. 2B). The induction was transient: 

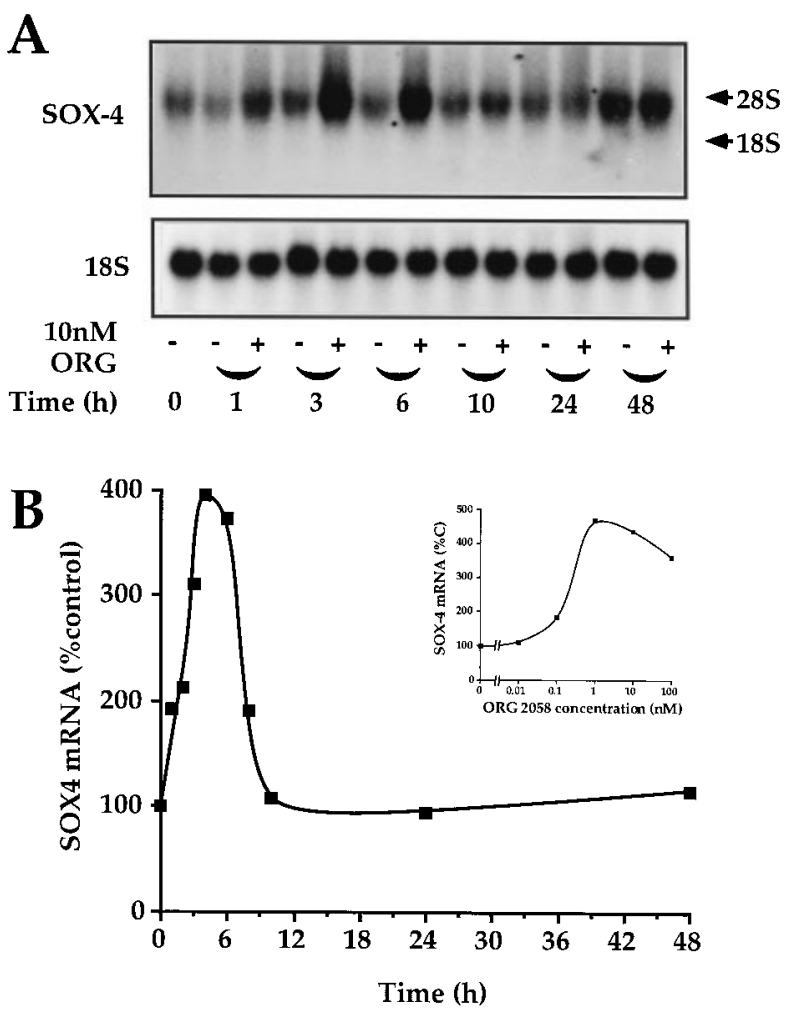

FIGURE 2. Induction of SOX4 mRNA by ORG 2058. T-47D cells growing in phenol red-free RPMI 1640 medium supplemented with $5 \% \mathrm{FCS}$ were changed to medium containing 5\% charcoal-treated FCS $24 \mathrm{~h}$ before treatment. (A) Cells were treated with 10 nM ORG 2058 or vehicle and harvested at the times shown. Total RNA was prepared and SOX4 mRNA was detected by Northern blot analysis. The locations of the $18 \mathrm{~S}$ and $28 \mathrm{~S}$ rRNA subunits are indicated. The same blot was probed using an oligonucleotide hybridizing to the $18 \mathrm{~S}$ rRNA to check loading, shown in the lower panel. (B) SOX4 mRNA levels were quantified densitometrically and are expressed as a percentage of the time-matched vehicle-treated control. The data represent the combined results of three separate experiments. Inset: T-47D cells growing in phenol red-free RPMI 1640 medium supplemented with $5 \% \mathrm{FCS}$ were changed to medium containing 5\% charcoal-treated FCS 24 h before treatment. Cells were treated with the range of ORG 2058 concentrations shown or vehicle and harvested $4 \mathrm{~h}$ later. SOX4 mRNA levels are shown as a percentage of the vehicle-treated control $(\% \mathrm{C})$.

by $8 \mathrm{~h}$ after treatment the SOX 4 mRNA level had decreased to less than 2-fold the time-matched control and by $10 \mathrm{~h}$ had returned to control levels (Fig. 2B). At 24 and $48 \mathrm{~h}$ after treatment SOX4 mRNA remained at control levels. The progestin effect on SOX4 mRNA was concentration-dependent (Fig. 2B inset). When
A
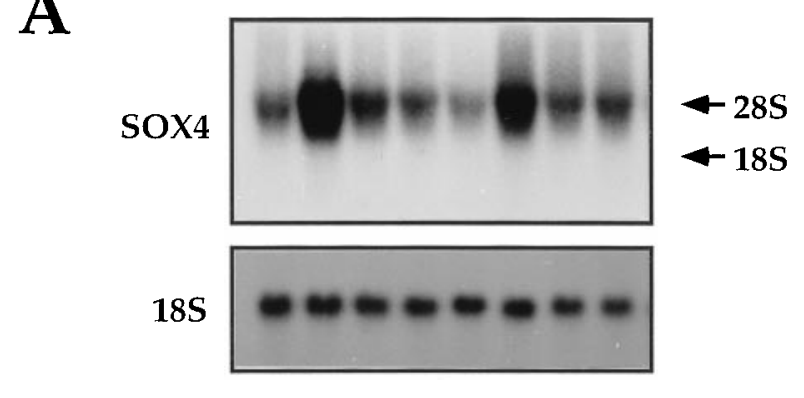

B

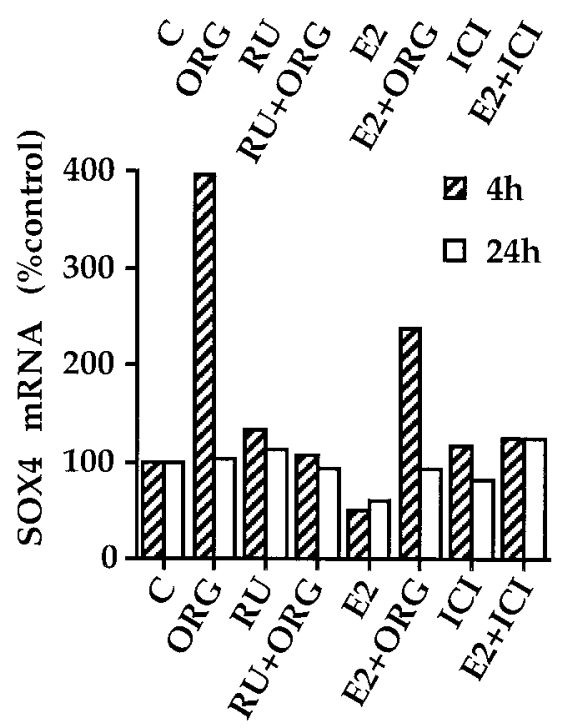

FIGURE 3. Effect of anti-progestins, oestrogen and anti-oestrogen on SOX4 mRNA levels. T-47D cells growing in phenol red-free RPMI 1640 medium supplemented with $5 \% \mathrm{FCS}$ were changed to medium containing 5\% charcoal-treated FCS 24 h before treatment. Cells were treated with vehicle, $10 \mathrm{nM} \mathrm{ORG}$ 2058, $100 \mathrm{nM}$ RU 38486, $1 \mathrm{nM}$ oestrogen (E2) or $100 \mathrm{nM}$ ICI 182780 , in the combinations indicated, and harvested at 4 and $24 \mathrm{~h}$ for preparation of total RNA. The same blot was probed using an oligonucleotide hybridizing to the $18 \mathrm{~S}$ rRNA to check loading, shown in the lower panel. SOX4 mRNA was quantified densitometrically and expressed as a percentage of the time-matched vehicle-treated control.

SOX 4 mRNA levels were examined after $4 \mathrm{~h}$ treatment with $0 \cdot 01$ to $100 \mathrm{nM}$ ORG 2058, maximal induction of SOX4 mRNA was observed at $1 \mathrm{nM}$. To determine whether progestin regulation of SOX4 was mediated by PR, the effects of a progestin antagonist were examined after 4 or $24 \mathrm{~h}$ of treatment (Fig. 3). The anti-progestin, RU 38486, had no effect on SOX4 mRNA levels alone at either time, but completely abrogated the ORG 2058 effect at $4 \mathrm{~h}$, showing that the progestin effect was PR-mediated. Treatment with $17 \beta$-oestradiol 
decreased SOX4 mRNA levels and partially abrogated the progestin-mediated effect (Fig. 3). Treatment with the anti-estrogen ICI 182780 abrogated the effects of oestradiol (Fig. 3).

\section{Progestin regulation of SOX4 mRNA was transcriptionally mediated}

To determine whether the progestin induction of $S O X 4$ expression was due to increased transcription, $S O X 4$ gene transcription was measured in nuclei isolated from T-47D cells which had been treated for $2 \mathrm{~h}$ with $10 \mathrm{nM}$ ORG 2058 or vehicle (Fig. 4). Progestins markedly increased SOX4 transcription compared with the matched control, both in the presence and absence of the protein synthesis inhibitor, cycloheximide, showing that the progestin effect was transcriptionally mediated and suggesting that it was direct.

\section{Effect of progestins on other $S O X$ genes}

Northern blots were hybridized with probes homologous to SOX2, SOX3, Sox9, SOX11, Sox21 and SOX22. SOX2, SOX3 and SOX11 mRNA were undetectable in T-47D cells, and hormone treatment did not increase their levels to within the detectable range. Sox 9 was detected at a low level and its expression was not modulated by hormone treatment (data not shown). A single transcript migrating between the $28 \mathrm{~S}$ and $18 \mathrm{~S}$ rRNA transcripts was identified upon hybridization of Northern blots at low stringency with a mouse Sox 21 probe; as the human SOX21 has yet to be described, this transcript was assumed to represent human SOX21 mRNA: no regulation of this transcript by hormonal treatment was noted (not shown). SOX22 was detected by Northern blot analysis of T-47D cells and no consistent effect of hormone treatment was noted (data not shown). In order to determine whether the expression of $S O X$ genes, other than those tested above, was influenced by ORG 2058 treatment, poly(A) ${ }^{+}$RNA from vehicle- or progestin-treated cells was probed at low stringency with a cDNA flanking and including the SOX4 HMG box (SOXF1R1; Fig. 5). This detected a progestin-regulated transcript of a size consistent with SOX4, in keeping with the data shown above, but no other transcripts of significant abundance, and there was no evidence of progestin regulation of transcripts other than SOX4.

\section{Induction of $S O X 4$ transcriptional activity by progestins}

The induction of SOX4 gene expression by progestins was reflected in an induction of SOX4

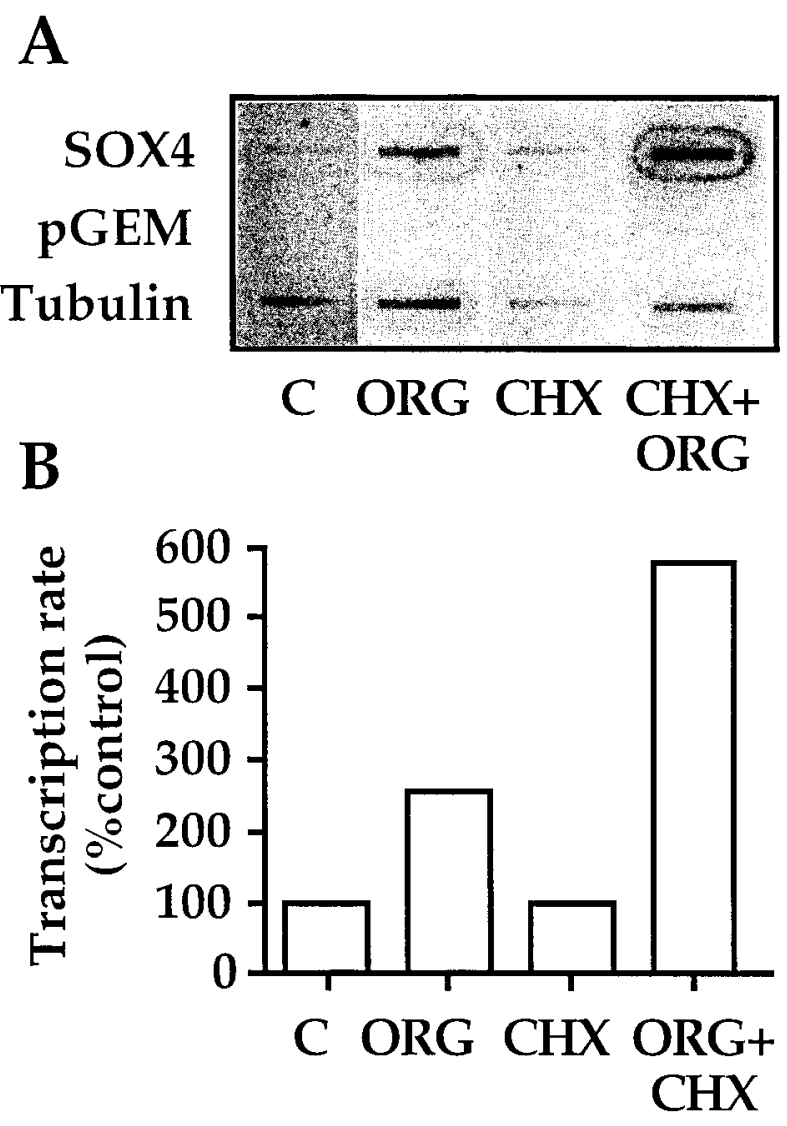

FIGURE 4. Regulation of SOX4 transcription rate. T-47D cells growing in phenol red-free RPMI 1640 medium supplemented with $5 \%$ FCS were changed to medium containing 5\% charcoal-treated FCS 24 h before treatment for $2 \mathrm{~h}$ with $10 \mathrm{nM}$ ORG 2058 or vehicle, in the presence or absence of $20 \mu \mathrm{g} / \mathrm{ml}$ cycloheximide (CHX). Cells were harvested and nuclei were prepared by lysis at $4{ }^{\circ} \mathrm{C}$ in a Nonidet P40 buffer. (A) SOX 4 and $\alpha$-tubulin transcription rates were estimated using the nuclear run-on technique. The pGEM-7Zf(+) plasmid was used as a negative control. The results were scanned and analysed using a Molecular Dynamics PhosphorImager and Imagequant software. To control for differences in hybridization the SOX4 signal was normalized using the $\alpha$-tubulin signal on the same filter. (B) SOX4 transcription rate was estimated by densitometry and is expressed as a percentage of the vehicle-treated control, after normalization for differences in hybridization using $\alpha$-tubulin.

transcriptional activity. When the pBL2CAT$[\mathrm{SOX} 4]_{4}$ construct, which contains four SOX consensus motifs upstream of the thymidine kinase promoter and CAT reporter sequences, was transiently transfected into T-47D cells, ORG 2058 treatment resulted in a greater than 50 -fold increase in CAT activity (Fig. 6). No effect of ORG 2058 treatment was seen if the same pBL2CAT vector 

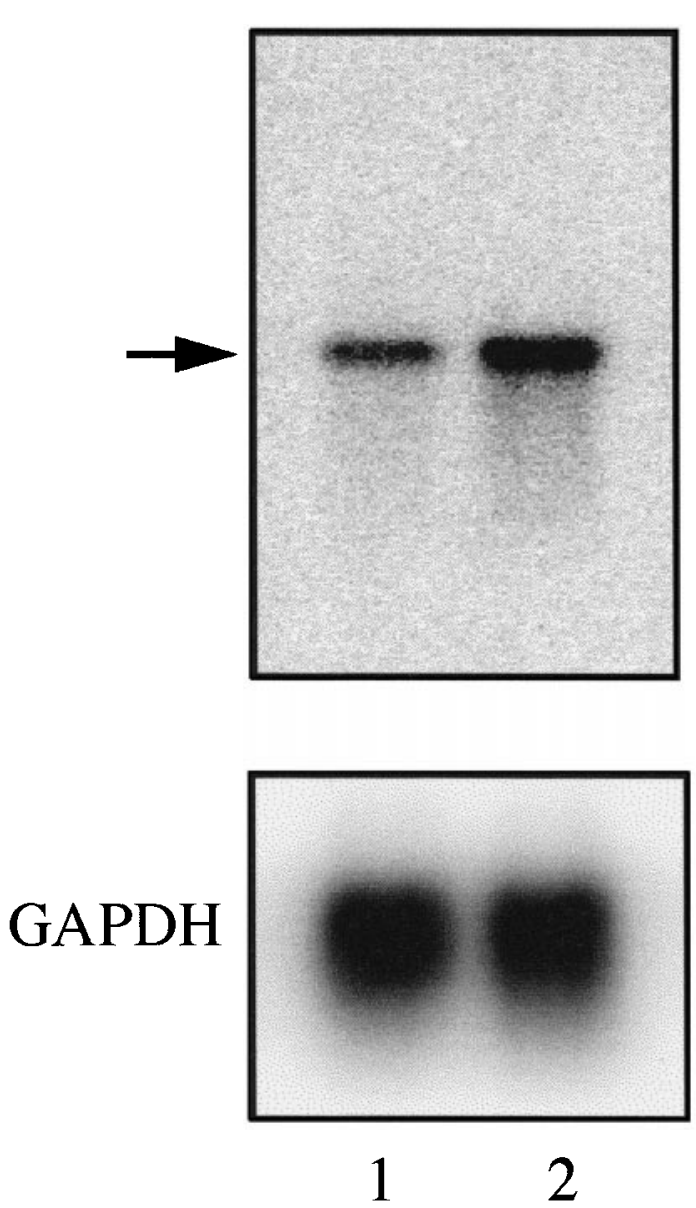

FIGURE 5. Effect of ORG2058 on expression of SOX genes other than $S O X 4$ in T-47D cells. T-47D cells growing in phenol red-free RPMI 1640 medium supplemented with $5 \%$ FCS were treated with vehicle (lane 1) or $10 \mathrm{nM}$ ORG 2058 (lane 2) and harvested at 4 h. Poly $(\mathrm{A})^{+}$RNA was prepared, blotted and probed with the SOXF1R1 cDNA, which flanks and includes the SOX4 HMG box. The same blot was probed using a GAPDH probe to check loading, shown in the lower panel. Only one major transcript (arrowed), consistent in size and progestin regulation with SOX 4 mRNA, was detected. A second, minor, transcript was detected after prolonged exposure but no regulation of this transcript was noted (not shown).

with an oestrogen-responsive sequence replacing the SOX consensus motifs was transfected (not shown), demonstrating that the effect was mediated through the SOX consensus region. RU 38486 had little effect alone but completely abolished the progestin effect, showing that the induction was PR-mediated. Transactivation of pBL2CAT$[\mathrm{SOX} 4]_{4}$ could be contributed by other SOX proteins, as the motif represents a consensus binding element for SRY-related proteins. How-

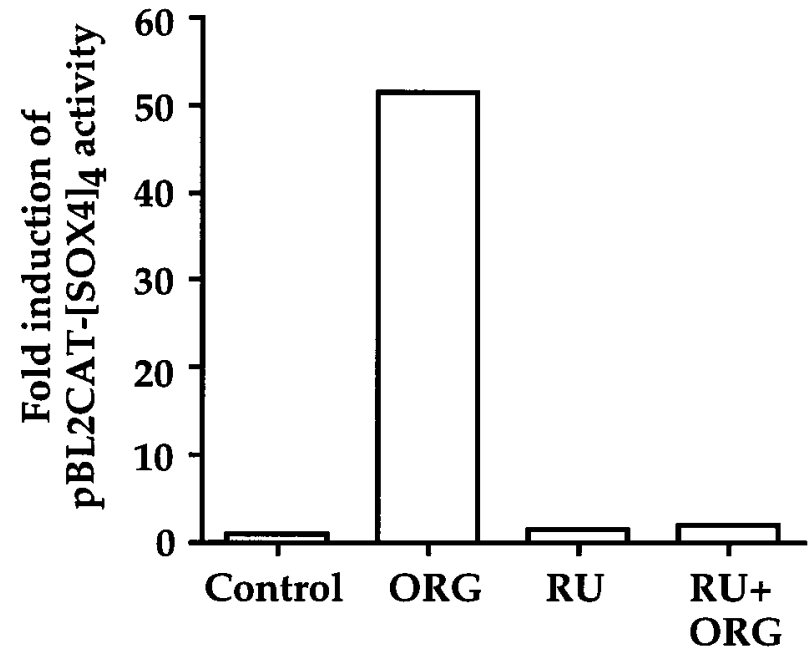

FIgURE 6. Transfection of a SOX4 reporter construct into T-47D cells. (A) T-47D cells were transfected with pBL2CAT-[SOX4 $]_{4}$ and the pCH110 $\beta$-galactosidase control plasmid. At $4 \mathrm{~h}$ after addition of precipitates, cells were treated with $10 \mathrm{nM}$ ORG 2058 and $100 \mathrm{nM}$ RU 38486 separately or combined as indicated. The cells were harvested $28 \mathrm{~h}$ after transfection, and CAT and $\beta$-galactosidase activities were determined. The results are expressed as fold induction of CAT relative to control, after correction using $\beta$-galactosidase activity. Each data point represents the results of triplicate transfections and is representative of two experiments where the same results were seen. Error bars are not visible because the magnitude of the error fell below the resolution of the bar graph. No effect of ORG 2058 was noted when the plasmid lacked the SOX motif, shown when transfections were repeated with an oestrogenresponsive sequence in place of the SOX-responsive sequences (data not shown).

ever, the basal activation of the reporter was very low, suggesting that endogenous SOX protein expression is low in these cells. Furthermore, there was no evidence, from the experiments described above, of progestin regulation of $S O X$ genes apart from SOX4 in T-47D cells.

\section{Expression of SOX4 mRNA in normal breast and breast cancer cell lines}

SOX4 mRNA was detected in the normal breast, albeit at levels lower that those seen in progestintreated T-47D cells, and was detectable in total RNA (Fig. 7). The higher level of SOX4 mRNA in T-47D breast cancer cells when compared with normal breast was noted more generally in a range of breast cancer cell lines: SOX4 mRNA was detected in all cell lines tested, and the majority of cell lines had SOX4 levels similar to those found in 


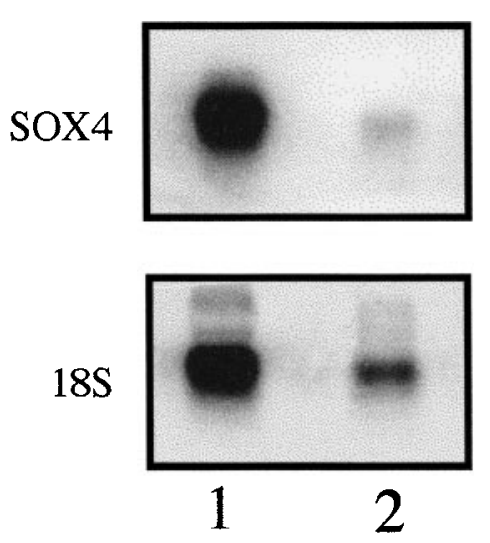

FIGURE 7. Expression of SOX $4 \mathrm{mRNA}$ in normal breast. Northern blots of total RNA from T-47D cells treated with $10 \mathrm{~nm}$ ORG 2058 for $4 \mathrm{~h}$ (lane 1) and from normal breast tissue (lane 2) were hybridized with a SOX4 cDNA (top panel). The same blot was probed for $18 \mathrm{~S}$ rRNA to check loading, shown in the lower panel.

T-47D cells. Interestingly, two breast cancer cell lines, MDA-MB-361 and the MDA-MB-134, expressed markedly higher SOX4 levels (Fig. 8).

\section{DISCUSSION}

This is the first report of regulation by steroid hormones of a member of the $S O X$ gene family. The SOX4 gene was transcribed in PR-positive T-47D breast cancer cells, and SOX4 mRNA was rapidly induced by progestins. The effect was concentrationdependent, with maximal induction being seen with 1nM ORG 2058 treatment. SOX4 was the most abundant member of the $S O X$ gene family detected in these cells; moreover, progestin regulation of $S O X$ gene expression was restricted to $\mathrm{SOX} 4$ and was not noted for a range of other $S O X$ genes tested.

The induction of SOX 4 mRNA by progestins in breast cancer cells was reflected in an increase in SOX transcriptional activity, as progestins caused a marked induction of the pBL2CAT-[SOX4 $]_{4}$ reporter containing four SOX4 motifs inserted upstream of TK-CAT. This activity could be contributed by other SOX proteins, as the motif represents a consensus binding element for SRYrelated proteins. However, two lines of evidence argue against this: first, there was no evidence of progestin modulation of $S O X$ genes apart from $S O X 4$ in these cells. Secondly, the basal activation of the reporter gene was very low compared with the strong activity upon progestin induction, suggesting that endogenous SOX expression is low in these cells and that the observed effects are progestin specific, and likely to be mediated through SOX4.
A

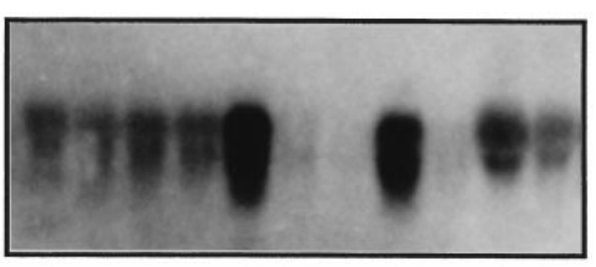

$18 S$

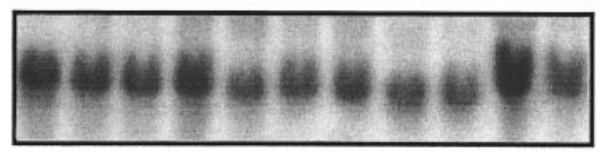

B

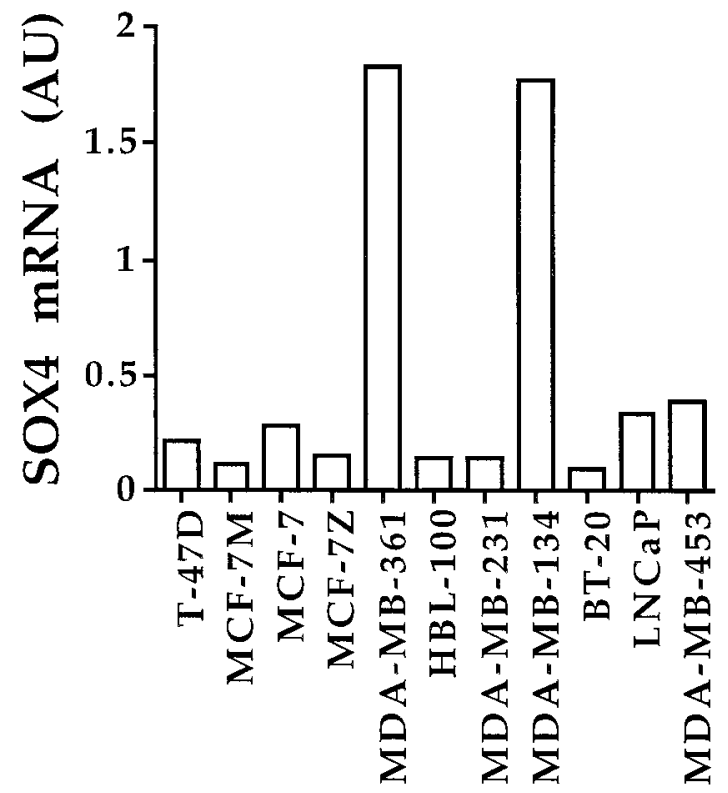

FIGURE 8. Expression of SOX4 mRNA in breast cancer cells. Total RNA isolated from nine breast cancer cell lines (ER+ cells: T-47D, MCF-7M, MCF-7, MCF-7Z, MDA-MB-361, MDA-MB-134 and ER-cells: MDA-MB-231, BT-20, MDA-MB-453), HBL-100transformed breast epithelial cells and the $\mathrm{LNCaP}$ prostate carcinoma cell line was analysed by Northern blotting (20 $\mathrm{\mu g} / \mathrm{sample})$ as described in Materials and Methods (A). (B) SOX4 mRNA levels were quantified by densitometry. The same blot was probed for $18 \mathrm{~S}$ rRNA, SOX4 levels were normalized for differences in loading and the data depicted as arbitrary units (AU).

It is unlikely that transcription factors other than SOX proteins, for instance $\mathrm{PR}$, bind and activate the pBL2CAT-[SOX4] 4 reporter. The SOX4 motif has little resemblance to a progestin-responsive element (Gronemeyer 1991, Tsai \& O'Malley 1994). Similarly, the AP1 transcription complex, which mediates the effects of hormones, growth factors and cytokines on a number of target genes (Angel \& Karin 1991), is not likely to mediate the effects of 
progestins on the pBL2CAT-[SOX4] $]_{4}$ reporter. The AP1-recognition sequence differs markedly from the SOX motif and, furthermore, progestins have been shown to negatively regulate an AP1 reporter, rather than to induce its activity (Shemshedini et al. 1991, Alkhalaf \& Murphy 1992).

Progestin regulation of SOX 4 mRNA was clearly PR-mediated as the induction was completely abrogated by the progestin antagonist RU 38486 . Transcriptional run-on analysis revealed that progestin induction of SOX 4 mRNA occurred through an increase in the transcription rate of the SOX4 gene. Cotreatment with the protein synthesis inhibitor, cycloheximide, was unable to abolish this effect, suggesting that it is directly mediated through PR binding to the $S O X 4$ gene. This was consistent with the rapidity of SOX 4 mRNA induction, which resulted in almost 2 -fold induction within $1 \mathrm{~h}$ of progestin exposure. The superinduction of SOX4 transcription by progestins in the presence of cycloheximide may reflect stabilization of SOX4 transcripts as the result of downregulation by the protein synthesis inhibitor of nuclear RNases normally responsible for turnover of nascent transcripts. It can be concluded that progestins increase the SOX4 transcription rate in both the presence and absence of cycloheximide, indicating that PR exerts direct transcriptional control on the SOX 4 gene.

Although SOX4 expression and regulation have been described in most detail here in malignant breast cancer cells, SOX 4 mRNA was also detected in the normal human breast, highlighting the possibility that the SOX4 gene plays a developmental role in normal progestin-responsive tissues in the adult. Such a role would be comparable, in some respects, to the part played by many of the $S O X$ genes in the development of neural tissues, central and peripheral nervous systems and skeletal tissue during embryogenesis (Denny et al. 1992, Stevanovic et al. 1993, Connor et al. 1994, 1995, Foster et al. 1994, Wagner et al. 1994, Uwanogho et al. 1995), and may provide a mechanism for the complex cell specificity of progestin action in target tissues.

The mammary gland is remarkable in being present only in rudimentary form in the neonate, with the major stages of its development taking place consequent to exposure to ovarian hormones in the adolescent and during pregnancy. Progesterone plays an essential role in regulating the growth and differentiation of the mammary gland (Lydon et al. 1995) and is essential for opposing the proliferative effects of oestrogen in specific cell types (Clarke \& Sutherland et al. 1990). The mechanisms mediating the effects of progesterone in the reproductive system are not understood and the demonstration that expression of the $\mathrm{SOX} 4$ gene is increased by progestin implies that SOX 4 may be a candidate mediator of the effects of progesterone in target tissues. In addition, SOX4 may cooperate with ovarian hormones in controlling transcription; transactivation studies of Sox genes now indicate that this protein cooperates with other transcriptional regulators to affect gene expression (van de Wetering et al. 1993, McCracken et al. 1997, Botquin et al. 1998, Kuhlbrodt et al. 1998, Lamb \& Rizzino 1998).

The demonstration of the effects of progestin on $S O X 4$ gene expression in breast cancer cells and the identification of $\mathrm{SOX}_{4}$ gene expression in breast tumours (unpublished observations) suggest that hormonal alterations in $S O X 4$ gene expression may play a role in malignant breast tissue. More broadly, ovarian hormone control of SOX4 expression may indicate a role for this gene family in postnatal development of the mammary gland.

\section{ACKNOWLEDGEMENTS}

Supported by grants from the National Health and Medical Research Council of Australia, the New South Wales Cancer Council and the Westmead Hospital Foundation. J D G was supported by a Dora Lush Biomedical Postgraduate Scholarship from the National Health and Medical Research Council of Australia and is now a National Health and Medical Research Council of Australia C J Martin Fellow.

\section{REFERENCES}

Alkhalaf M \& Murphy LC 1992 Regulation of c-jun and jun-B by progestins in T-47D human breast cancer cells. Molecular Endocrinology 6 1625-1633.

Altschul SF, Gish W, Miller W, Myers EW \& Lipman DJ 1990 Basic local alignment search tool. Fournal of Molecular Biology 215 403-410.

Angel P \& Karin M 1991 The role of Jun, Fos and the AP-1 complex in cell-proliferation and transformation. Biochimica et Biophysica Acta 1072 129-157.

Botquin V, Hess H, Fuhrmann G, Anastassiadis C, Gross MK, Vriend G \& Scholer HR 1998 New POU dimer conformation mediates antagonistic control of an osteopontin preimplantation enhancer by Oct-4 and Sox-2. Genes and Development 12 2073-2090.

Clarke CL \& Sutherland RL 1990 Progestin regulation of cellular proliferation. Endocrine Reviews 11 266-301.

Clarke CL, Graham J, Roman SD \& Sutherland RL 1991 Direct transcriptional regulation of the progesterone receptor by retinoic acid diminishes progestin responsiveness in the breast cancer cell line T-47D. Fournal of Biological Chemistry 266 18969-18975. 
Clarke CL, Roman SD, Graham J, Koga M \& Sutherland RL 1990 Progesterone receptor regulation by retinoic acid in the human breast cancer cell line T-47D. Fournal of Biological Chemistry 265 12694-12700.

Connor F, Cary PD, Read CM, Preston NS, Driscoll PC, Denny P, Crane-Robinson C \& Ashworth A 1994 DNA binding and bending properties of the post-meiotically expressed Sry-related protein Sox-5. Nucleic Acids Research 22 3339-3346.

Connor F, Wright E, Denny P, Koopman P \& Ashworth A 1995 The Sry-related HMG box-containing gene Sox6 is expressed in the adult testis and developing nervous system of the mouse. Nucleic Acids Research 23 3365-3372.

Cowan NJ, Dobner PR, Fuchs EV \& Cleveland DW 1983 Expression of human alpha-tubulin genes: interspecies conservation of $3^{\prime}$ untranslated regions. Molecular and Cellular Biology 3 1738-1745.

Denny P, Swift S, Connor F \& Ashworth A 1992 An SRYrelated gene expressed during spermatogenesis in the mouse encodes a sequence-specific DNA-binding protein. EMBO Fournal 11 3705-3712.

Farr CJ, Easty DJ, Ragoussis J, Collignon J, Lovell-Badge R \& Goodfellow PN 1993 Characterization and mapping of the human SOX 4 gene. Mammalian Genome 4 577-584.

Ferrari S, Harley VR, Pontiggia A, Goodfellow PN, LovellBadge R \& Bianchi ME 1992 SRY, like HMG1, recognizes sharp angles in DNA. EMBO Fournal 11 4497-4506.

Foster JW, Dominguez-Steglich MA, Guioli S, Kwok C, Weller PA, Stevanovic M, Weissenbach J, Mansour S, Young ID, Goodfellow PD, Brook JD \& Schafer AJ 1994 Campomelic dysplasia and autosomal sex reversal caused by mutations in an SRY-related gene. Nature 372 $525-530$.

Gorman C 1985 High efficiency gene transfer into mammalian cells. In DNA Cloning VII A Practical Approach, pp 143-165. Ed DM Glover. Oxford: IRL Press.

Greenberg ME \& Ziff EB 1984 Stimulation of 3T3 cells induces transcription of the $c$-fos proto-oncogene. Nature 311 $433-438$.

Gronemeyer H 1991 Transcription activation by estrogen and progesterone receptors. Annual Review of Genetics 25 89-123.

Gubbay J, Collignon J, Koopman P, Capel B, Economou A, Munsterberg A, Vivian N, Goodfellow P \& Lovell-Badge R 1990 A gene mapping to the sex-determining region of the mouse $\mathrm{Y}$ chromosome is a member of a novel family of embryonically expressed genes. Nature 346 245-250.

Hosking BM, Muscat GEO, Koopman PA, Dowhan DH \& Dunn TL 1995 Trans-activation and DNA-binding properties of the transcription factor, Sox-18. Nucleic Acids Research 23 2626-2628.

Kastner P, Krust A, Turcotte B, Stropp U, Tora L, Gronemeyer H \& Chambon P 1990 Two distinct estrogenregulated promoters generate transcripts encoding the two functionally different human progesterone receptor forms A and B. EMBO Fournal 9 1603-1614.

Keydar I, Chen L, Karby S, Weiss FR, Delarea J, Radu M, Chaitcik S \& Brenner HJ 1979 Establishment and characterization of a cell line of human breast carcinoma origin. European Fournal of Cancer 15 659-670.

Kuhlbrodt K, Herbarth B, Sock E, Enderich J, HermansBorgmeyer I \& Wegner M 1998 Cooperative functions of POU proteins and SOX proteins in glial cells. Fournal of Biological Chemistry 273 16050-16057.

Lamb KA \& Rizzino A 1998 Effects of differentiation on the transcriptional regulation of the FGF-4 gene: critical roles played by the distal enhancer. Molecular Reproduction and Development $51218-224$.
Laudet V, Stehelin D \& Clevers H 1993 Ancestry and diversity of the HMG box superfamily. Nucleic Acids Research 21 2493-2501.

Liang P \& Pardee AB 1992 Differential display of eukaryotic messenger RNA by means of the polymerase chain reaction. Science 257 967-971.

Liang P, Averboukh L \& Pardee AB 1993 Distribution and cloning of eukaryotic mRNAs by means of differential display: refinements and optimization. Nucleic Acids Research 21 3269-3275.

Lydon JP, DeMayo FJ, Funk CR, Mani SK, Hughes AR, Montgomery Jr CA, Shyamala G, Conneely OM \& O'Malley BW 1995 Mice lacking progesterone receptor exhibit pleiotropic reproductive abnormalities. Genes and Development 9 2266-2278.

McCracken S, Kim CS, Xu Y, Minden M \& Miyamoto NG 1997 An alternative pathway for expression of $\mathrm{p} 56^{\text {lck }}$ from type I promoter transcripts in colon carcinoma. Oncogene 15 2929-2937.

Pevny LH \& Lovell-Badge R 1997 Sox genes find their feet. Current Opinion in Genetics and Development 7 338-344.

Sambrook J, Fritsch EF \& Maniatis T 1989 Molecular Cloning: A Laboratory Manual. Cold Spring Harbor, NY: Cold Spring Harbor Laboratory Press.

Schilham MW, Oosterwegel MA, Moerer P, Ya J, de Boer PAJ, van de Wetering M, Verbeek S, Lamers WH, Kruisbeek AM, Cumano A \& Clevers H 1996 Defects in cardiac outflow tract formation and pro-B-lymphocyte expansion in mice lacking Sox-4. Nature 380 711-714.

Shemshedini L, Knauthe R, Sassone-Corsi P, Pornon A \& Gronemeyer H 1991 Cell-specific inhibitory and stimulatory effects of Fos and Jun on transcription activation by nuclear receptors. EMBO Fournal 10 3839-3849.

Stevanovic M, Lovell-Badge R, Collignon J \& Goodfellow PN 1993 SOX3 is an X-linked gene related to SRY. Human Molecular Genetics 2 2013-2018.

Tani M, Shindo-Okada N, Hashimoto Y, Shiroishi T, Takenoshita S, Nagamachi Y \& Yokota J 1997 Isolation of a novel Sry-related gene that is expressed in high-metastatic K-1735 murine melanoma cells. Genomics 39 30-37.

Tsai M-J \& O'Malley BW 1994 Molecular mechanisms of action of steroid/thyroid receptor superfamily members. Annual Review of Biochemistry 63 451-486.

Uwanogho D, Rex M, Cartwright EJ, Pearl G, Healy C, Scotting PJ \& Sharpe PT 1995 Embryonic expression of the chicken Sox2, Sox3 and Sox11 genes suggests an interactive role in neuronal development. Mechanisms of Development 49 23-36.

Wagner T, Wirth J, Meyer J, Zabel B, Held M, Zimmer J, Pasantes J, Dagna Bricarelli F, Keutel J, Hustert E, Wolf U, Tommerup N, Schempp W \& Scherer G 1994 Autosomal sex reversal and campomelic dysplasia are caused by mutations in and around the SRY-related gene SOX9. Cell 79 1111-1120.

van de Wetering M \& Clevers H 1992 Sequence-specific interaction of the HMG box proteins TCF-1 and SRY occurs within the minor groove of a Watson-Crick double helix. EMBO fournal 11 3039-3044.

van de Wetering M, Oosterwegel M, van Norren K \& Clevers H 1993 Sox-4, an Sry-like HMG box protein, is a transcriptional activator in lymphocytes. EMBO fournal 12 3847-3854.

Wright E, Hargrave MR, Christiansen J, Cooper L, Kun J, Evans T, Gangadharan U, Greenfield A \& Koopman P 1995 The Sry-related gene Sox9 is expressed during chondrogenesis in mouse embryos. Nature Genetics 9 15-20.

REVISED MANUSCRIPT RECEIVED 9 November 1998 